\title{
Preferences and beliefs of Dutch orthopaedic surgeons and patients reduce the implementation of "Choosing Wisely" recommendations in degenerative knee disease
}

\author{
T. Rietbergen ${ }^{1} \cdot$ R. L. Diercks ${ }^{2} \cdot$ I. Anker-van der Wel ${ }^{1}$ - M. E. van den Akker-van Marle ${ }^{1}$ N. Lopuhaä ${ }^{3}$. \\ R. P. A. Janssen ${ }^{4} \cdot$ H. M. J. van der Linden-van der Zwaag ${ }^{5} \cdot$ R. G. H. H. Nelissen ${ }^{5}$ • P. J. Marang-van de Mheen ${ }^{1}$. \\ L. van Bodegom-Vos ${ }^{1}$ (D)
}

Received: 14 February 2019 / Accepted: 11 September 2019 / Published online: 25 September 2019

(c) The Author(s) 2019

\begin{abstract}
Purpose The purpose of this study was to assess which factors were associated with the implementation of "Choosing Wisely" recommendations to refrain from routine MRI and arthroscopy use in degenerative knee disease.

Methods Cross-sectional surveys were sent to 123 patients (response rate 95\%) and 413 orthopaedic surgeons (response rate $62 \%$ ) fulfilling the inclusion criteria. Univariate and multivariate logistic regression analyses were used to identify factors associated with implementation of "Choosing Wisely" recommendations.

Results Factors reducing implementation of the MRI recommendation among patients included explanation of added value by an orthopaedic surgeon [OR 0.18 (95\% CI 0.07-0.47)] and patient preference for MRI [OR 0.27 (95\% CI 0.08-0.92)]. Factors reducing implementation among orthopaedic surgeons were higher valuation of own MRI experience than existing evidence [OR 0.41 (95\% CI 0.19-0.88)] and higher estimated patients' knowledge to participate in shared decision-making [OR 0.38 (95\% CI 0.17-0.88)]. Factors reducing implementation of the arthroscopy recommendation among patients were orthopaedic surgeons' preferences for an arthroscopy [OR 0.03 (95\% CI 0.00-0.22)] and positive experiences with arthroscopy of friends/family [OR 0.03 (95\% CI 0.00-0.39)]. Factors reducing implementation among orthopaedic surgeons were higher valuation of own arthroscopy experience than existing evidence [OR 0.17 (95\% CI 0.07-0.46)] and belief in the added value [OR 0.28 (95\% CI 0.10-0.81)].

Conclusions Implementation of "Choosing Wisely" recommendations in degenerative knee disease can be improved by strategies to change clinician beliefs about the added value of MRIs and arthroscopies, and by patient-directed strategies addressing patient preferences and underlying beliefs for added value of MRI and arthroscopies resulting from experiences of people in their environment.
\end{abstract}

Level of evidence IV.

Keywords Choosing Wisely $\cdot$ Degenerative knee disease $\cdot$ Magnetic resonance imaging $\cdot$ Knee arthroscopy . De-implementation $\cdot$ Barriers and facilitators

\section{Abbreviations \\ MRI Magnetic resonance imaging \\ CW Choosing Wisely}

L. van Bodegom-Vos

1.vanbodegom-vos@lumc.nl

1 Department of Biomedical Data Sciences, Section Medical Decision Making, Leiden University Medical Center, Postzone J10-s, P.O. Box 9600, 2300 RC Leiden, The Netherlands

2 Department of Orthopaedics, University Medical Center Groningen, Groningen, The Netherlands
3 ReumaNederland, Amsterdam, The Netherlands

4 Department of Orthopaedics, Máxima Medical Center, Eindhoven, The Netherlands

5 Department of Orthopaedics, Leiden University Medical Center, Leiden, The Netherlands 


\section{Introduction}

Approximately, $25 \%$ of patients aged 50 years and over experience knee symptoms from degenerative knee disease $[37,41]$. These patients suffer from pain during walking, climbing stairs and squatting, and have functional loss [15, 26]. In some cases, knee range of motion is limited due to a meniscal tear, also known as locking symptoms. These degenerative meniscal tears could be symptoms of early stage osteoarthritis $[18,19]$.

For diagnosing patients with degenerative knee disease, clinical practice guidelines $[2,4,7,8]$ and literature recommend weight-bearing radiographs (fixed flexion viewRosenberg view) to determine the presence and severity of degenerative knee disease and to exclude other causes of knee pain, such as osteonecrosis of the femoral condyle or tibial plateau [18, 45]. Although MRI has high sensitivity and specificity in detecting meniscal tears in older patients $[18,39]$, routine use of MRI is not recommended for diagnosis because of the poor correlation with patient symptoms [14, 19, 20,33]. Similarly, clinical practice guidelines do not recommend the use of arthroscopic surgery as there is no benefit shown of arthroscopic surgery over non-surgical treatments such as exercise therapy, analgesic medication and dietary advice $[2,17,18,27,29-31,37$, $38,43,44]$. If locking symptoms are present, or if pain is not reduced after non-surgical treatments, arthroscopy may be warranted. So, MRI and arthroscopic surgery without prior conservative management in degenerative knee disease can be considered as unnecessary or low value care as these provide no benefit for the patient, waste resources and may even cause harm to the patient $[17,35]$.

Although practice guidelines and the underlying evidence do not recommend routine use of MRI and arthroscopy, many patients aged 50 years and over with degenerative knee disease receive an MRI and/or a knee arthroscopy $[9,13,16,17,24,28,32,40]$. Arthroscopic knee surgery is even the most common orthopaedic procedure in countries with available data and is, on a global scale, performed more than two million times each year [37].

In an effort to reduce the unnecessary use of MRIs and knee arthroscopies for patients with degenerative knee disease, medical societies in several countries have formulated "Choosing Wisely" recommendations regarding their use $[1,3,6,10]$. A recent study of Rosenberg et al. [34] showed that developing such recommendations does not necessarily eradicate low value care. To stimulate the implementation of the $\mathrm{CW}$ recommendations, interventions should be adapted to the factors associated with implementation of specific CW recommendations-in this case 'do not order an MRI for suspected degenerative meniscal tears' and 'do not perform knee arthroscopy for patients with degenerative meniscal tears of degenerative knee disease without mechanical symptoms' [42]. Previous research has suggested that conducting knee arthroscopies is driven by clinician beliefs in the effectiveness [24, 28], the need to meet patient expectations [12], perverse financial incentives for clinicians/hospitals [24, 28], fragmented clinical decision pathways [24], and insurance coverage [32]. However, no study has systematically studied factors influencing the implementation of these $\mathrm{CW}$ recommendations on degenerative knee complaints in patients of 50 years and older.

Therefore, the aim of this study is to investigate which factors are associated with implementation of CW recommendations among patients and orthopaedic surgeons in the Netherlands which aim to reduce the number of unnecessary MRIs and arthroscopies in patients aged 50 years and over with degenerative knee disease. Based on the previous research above, it was hypothesized that orthopaedic surgeons' beliefs in the effectiveness of MRI and knee arthroscopy, the need to meet patient expectations, perverse financial incentives and insurance coverage all hamper the implementation of $\mathrm{CW}$ recommendations.

\section{Materials and methods}

To investigate which factors are associated with implementation of $\mathrm{CW}$ recommendations, cross-sectional online surveys were performed among Dutch patients $\geq 50$ years with degenerative knee disease and orthopaedic surgeons specialized in knee pathology (members of Dutch Knee Society) throughout the Netherlands. In the Netherlands, patients with (suspected) degenerative knee disease first visit a general practitioner before being referred to an orthopaedic surgeon.

A literature search and semi-structured interviews among Dutch patients with degenerative knee disease $(N=3)$ and orthopaedic surgeons $(N=3)$ were performed to identify potential factors influencing implementation of $\mathrm{CW}$ recommendations regarding MRIs and arthroscopies in patients $\geq 50$ years with degenerative knee disease. For the interviews, purposive sampling was applied to obtain contrasting views, thereby identifying a broad spectrum of potential factors. Patients $\geq 50$ years with degenerative knee problems who did and did not have an MRI and/or arthroscopy, and orthopaedic surgeons who either do or do not perform an MRI and/or arthroscopy in these patients were selected. The interview questions were based on the framework of Grol and Wensing [23]. This framework distinguishes factors influencing implementation at the following six levels: (a) innovation, (b) individual professional, (c) patient, (d) social context, (e) organisational context as well as the (f) economic and political context. 
The semi-structured interviews were audio-taped, fully transcribed and analysed using open coding. The qualitative analysis was performed using the software program ATLAS.ti (version 7.5.16). A total of 55 factors were identified from the literature $[21,22,25,36,46]$ for orthopaedic surgeons and patients. Besides, four factors were added based on the interviews among orthopaedic surgeons and patients. Overall, 59 factors were found, 26 for the patient and 33 for the orthopaedic surgeon.

\section{Survey for patients}

The survey included items about (1) background characteristics, (2) characteristics of the received care and (3) factors influencing implementation of the $\mathrm{CW}$ recommendations regarding MRI and arthroscopy. The items of these first two categories are given in "Appendix 1: Items survey patient". The third part of the survey about factors influencing implementation of the $\mathrm{CW}$ recommendations consisted of 26 items identified in the interviews and literature. Answers could be given on a 4-point Likert scale, ranging from "totally agree" (coded 1) to "totally disagree" (coded 4) and some questions could be answered with yes/no. If the patient underwent an MRI or arthroscopy, additional questions followed, for example on waiting time.

\section{Population}

Patients were recruited via advertisements in newspapers and on websites of patient organisations. Assuming a baseline implementation rate of $15 \%$ in those with a certain barrier for implementation, sample size calculations showed that at least 120 patients would be needed to be able to detect a twofold increase odds in those without the barrier with $80 \%$ power and $95 \%$ reliability. The developed survey was sent to a sample of patients with degenerative knee disease $(N=138)$. Inclusion criteria were: age $\geq 50$ years; degenerative knee disease; consultation with an orthopaedic surgeon for their degenerative knee disease. Patients on a waiting list for a total knee arthroplasty (TKA) or who already received a TKA were excluded. Also, patients with an inability to understand written Dutch were excluded. If patients indicated that they preferred to fill in the survey on paper rather than online, they received a paper survey. Two reminders were sent in case of non-response, one after 6 and one 12 weeks after the initial invitation. Patients received a ten euro gift card as an incentive upon completion of the survey.

\section{Survey for orthopaedic surgeons}

The survey for orthopaedic surgeons included items regarding (1) background characteristics, (2) characteristics of care delivery and (3) factors influencing implementation of the $\mathrm{CW}$ recommendations. The items of these first two categories are given in "Appendix 2: Items survey orthopaedic surgeon". The third part consisted of 33 items covering the factors influencing implementation of the $\mathrm{CW}$ recommendations for orthopaedic surgeons. Answers could be given on a 4-point Likert scale, ranging from "totally agree" (coded 1) to "totally disagree" (coded 4).

\section{Population}

All Dutch orthopaedic surgeons specialized in knee pathology listed with an email address in the registry of the Dutch Orthopaedic Association (NOV) were invited by email to participate in the current study $(N=422)$. Inclusion criterion was: treatment of patients $\geq 50$ years with degenerative knee symptoms. This criterion was asked as the first question of the survey. Non-responders received two reminders, one after 2 weeks and another 4 weeks after the initial invitation.

The Medical Ethical Committee (CME P16.190/NV/nv) of the Leiden University Medical Center confirmed that ethical approval for this type of study was not required under Dutch law.

\section{Statistical analysis}

Data from all respondents who completed the survey and fulfilled the inclusion criteria were included in the analyses. Descriptive statistics were used to describe the background characteristics, the care received by the patients, and characteristics of the care delivery according to the orthopaedic surgeon. The factors influencing implementation were dichotomized into agree ' 1 ' (totally agree and agree) and disagree ' 0 ' (totally disagree and disagree), because of few observations in some categories of the original Likert scale. If patients had an MRI and/or an arthroscopy, implemented $\mathrm{CW}$ recommendation was coded as 0 (no) and as 1 (yes) otherwise.

For patients, univariate logistic regression analysis was first used to assess which background characteristics, received care and potential factor for implementation were associated with the implemented $\mathrm{CW}$ recommendation, with MRI and arthroscopy (' 1 ' yes and ' 0 ' no) as the dependent variable. A similar analysis was conducted for orthopaedic surgeons, with self-reported implementation of the MRI/ arthroscopy recommendations (yes/no) as dependent variable and background characteristics, care delivery characteristics and the factors influencing implementation of the $\mathrm{CW}$ recommendations (agree/disagree) as independent variables.

In addition, for both patients and orthopaedic surgeons, a multivariate logistic regression analysis was performed including those background characteristics, characteristics of the received care/care delivery and the factors influencing 
the $\mathrm{CW}$ recommendations with a $p$ value $\leq 0.10$ in univariate analyses. All analyses were performed using the software package SPSS (IBM SPSS, version 23).

\section{Results}

Of the 138 recruited patients, 131 completed the survey (response rate 95\%). Fifteen were excluded because they did not fulfil the inclusion criteria ("Appendix 3: Flowcharts"). Of the 422 invited orthopaedic surgeons, 261 completed the survey (response rate $62 \%$ ). Nine were excluded because they did not treat any patients $\geq 50$ years with degenerative knee disease. Table 1 shows that the majority of the patients were female $(61 \%)$ receiving higher education $(47 \%)$, with average age 63.2 years. The majority of patients had additional coverage in their insurance (85\%). In the Netherlands, patients are obliged to have a basic insurance with or without an additional coverage. The basic insurance has a mandatory excess of 385 euro. Patients who completed the survey represented the target group well, compared to the characteristics of Dutch orthopaedic patients [5]. Most of the orthopaedic surgeons who responded were male $(90 \%)$, with an average age of 47.2 years and 12.0 years of working experience (Table 2). This was a realistic representation of the orthopaedic workforce in the Netherlands. The largest group worked in a general hospital (41\%) in the middle region of the Netherlands (42\%). Most of these orthopaedic surgeons saw more than 20 new patients per month (78\%).

\section{Factors influencing the use of MRI and arthroscopy among patients}

Table 3 shows that most patients agreed with the statements "Good contact with physical therapist helped me to persevere the physical therapy treatments" (90\%), "Good guidance of the physical therapist helped me to persevere all physical therapy treatments" (90\%), "I have an additional coverage" (85\%), and "Physical activity was difficult because of pain" (84\%).

Table 4 shows that undergoing an MRI was associated with five barriers and two background characteristics among patients. Undergoing a knee arthroscopy was associated with five barriers, three facilitators and one background characteristic. From these, the orthopaedic surgeon's explanation about the added value of an MRI [OR 0.18 (95\% CI $0.07-0.47)$ ] and the preference of the patient for an MRI [OR 0.27 (95\% CI 0.08-0.92)] remained as independent factors associated with reduced implementation of the $\mathrm{CW}$ recommendation regarding MRI, whereas a higher age [OR 1.07 (95\% CI 1.01-1.14)] was associated with higher implementation. For arthroscopy, the preference of the orthopaedic surgeon for arthroscopy [OR 0.03 (95\% CI 0.00-0.22)] and positive experiences of people in the patient's environment
[OR 0.03 (95\% CI 0.00-0.39)] remained as independent factors associated with reduced implementation of the $\mathrm{CW}$ recommendation regarding arthroscopy.

\section{Factors influencing the use of MRI and arthroscopy among orthopaedic surgeons}

Table 5 shows that most orthopaedic surgeons agreed with the statements "asking questions about the previous nonsurgical treatments" (98\%), the familiarity with the CW recommendation for MRI (99\%) and arthroscopy (98\%) as influential factors for implementation.

Table 6 shows that implementation of the CW recommendation regarding MRI was associated with four barriers and six facilitators among orthopaedic surgeons in univariate analysis. Implementation of the $\mathrm{CW}$ recommendation regarding arthroscopy was associated with two barriers, five facilitators and three background characteristics. From these, agreement with the $\mathrm{CW}$ recommendation regarding MRI [OR 12.10 (95\% CI 3.51-41.64)] remained as an independent factor associated with higher implementation of the $\mathrm{CW}$ recommendation in multivariate analysis, whereas higher valuation of own experience than existing evidence [OR 0.41 (95\% CI 0.19-0.88)] and higher estimated patients' knowledge to participate in shared decisionmaking [OR 0.38 (95\% CI 0.17-0.88)] were associated with reduced implementation. Knowledge of [OR 58.17 (95\% CI 2.63-1287.24)] and agreement with the CW recommendations regarding arthroscopy [OR 37.45 (95\% 5.39-260.24)] as well as actively searching for newest evidence and guidelines [OR 3.28 (95\% CI 1.19-9.08)] were associated with higher implementation of the $\mathrm{CW}$ recommendation regarding arthroscopy, whereas higher valuation of own experience than existing evidence [OR 0.17 (95\% CI 0.07-0.46)] and belief in the value of arthroscopy [OR 0.28 (95\% CI $0.10-0.81)]$ were associated with reduced implementation.

\section{Discussion}

That the implementation of $\mathrm{CW}$ recommendations to reduce unnecessary MRIs and knee arthroscopies was hampered by patient preferences for MRI, positive experiences with arthroscopies in the patient's environment, orthopaedic surgeons' preferences for arthroscopy and their beliefs in the added value as well as valuing their own clinical experience to be more important than existing evidence were the most important findings of this study. On the other hand, orthopaedic surgeons' knowledge of and agreement with the CW recommendations, as well as a proactive attitude towards searching for new evidence and guidelines facilitate implementation. Furthermore, older age of patients increased implementation of $\mathrm{CW}$ recommendations regarding MRI. 
Table 1 Background characteristics of patients and received care from a patient perspective $(n=116)$
Background characteristics

Age in years, mean (SD)

$63.2(7.9)$

Female, $n(\%)$

$71(61.2)$

Region of residence, $n(\%)$

North

$38(32.8)$

Middle

$68(58.6)$

South

$10(8.6)$

Education, $n(\%)$

Basic

8 (6.9)

Intermediate

$53(45.7)$

High

55 (47.4)

Start of symptoms of degenerative knee disease, $n(\%)$

$\leq 1$ year ago

18 (15.4)

$>1$ year ago

$98(84.5)$

$7(12.5)$

$7.1(2.2)$

$4.7(2.2)$

Pain at this moment (VAS), mean (SD)

17 (14.7)

Basic only

99 (85.3)

Basic with additional coverage

Received care

Patient visited $\ldots, n(\%)$

General practitioner (GP)

$103(88.8)$

Physical therapist

$85(73.3)$

Dietician

$10(8.6)$

Other primary care specialists

$13(11.2)$

Patient underwent $\ldots, n(\%)$

MRI scan

$74(63.8)$

Arthroscopy

$56(48.3)$

Time between the start of knee complaints and the consultation with the general practitioner, $n(\%)^{\mathrm{c}}$

$\leq 6$ weeks

$47(51.1)$

$>6$ weeks

$45(48.9)$

Time between consultation with the general practitioner and orthopaedic surgeon, $n(\%)^{\mathrm{d}}$

$\leq 6$ weeks

$83(80.6)$

$>6$ weeks

$20(19.4)$

Waiting time for MRI scan ${ }^{\mathrm{b}}, n(\%)$

$\leq 2$ weeks

$40(66.7)$

$>2$ weeks

$20(33.3)$

Waiting time for arthroscopy ${ }^{\mathrm{a}}$

$\leq 2$ weeks

$11(23.9)$

$>2$ weeks

$35(76.1)$

Implementation of $\mathrm{CW}$ recommendation regarding MRI/arthroscopy, $n$ (yes), $\%$

MRI, $n(\%)$

Arthroscopy, $n(\%)$

$n=116$

${ }^{\mathrm{a}} n=46$

${ }^{\mathrm{b}} n=60$

${ }^{\mathrm{c}} n=92$

${ }^{\mathrm{d}} n=103$

${ }^{\mathrm{e}} n=56$

${ }^{\mathrm{f}}$ Pain measured on a visual analogue scale (VAS), 0 (no pain)—10 (unbearable pain) 
Table 2 Background characteristics of orthopaedic surgeons, characteristics of care delivery and implementation of MRI/arthroscopy clinical guidelines $(n=252)$
Background characteristics

Age in years, (mean, SD) ${ }^{\mathrm{a}}$

$47.2(8.5)$

Female, $n(\%)$

$25(9.9)$

Years of work experience as orthopaedic surgeon (mean, SD)

$12.0(8.0)$

Work region, $n(\%)$

North

85 (33.7)

Middle

105 (41.7)

South

$62(24.6)$

New patients $\geq 50$ years with knee complaints seen per month, $n(\%)$

$0-1$

$1(0.4)$

2-5

9 (3.6)

6-10

$12(4.8)$

$11-20$

34 (13.5)

$>20$

$196(77.8)$

Number of MRI scans ordered per month, $n(\%)$

$0-1$

$70(27.8)$

$2-5$

$81(32.1)$

$6-10$

$55(21.8)$

$11-20$

35 (13.9)

$>20$

$11(4.4)$

Number of arthroscopies carried out per month, mean (SD)

$0-1$

$107(42.5)$

$2-5$

$97(38.5)$

$37(14.7)$

9 (3.6)

$11-20$

$2(0.8)$

$>20$

Percentage of patients $\geq 50$ years undergoing an arthroscopy because of locking symptoms, $n(\%)$

$0-10 \%$

$41(16.3)$

$11-20 \%$

$11(4.4)$

$21-30 \%$

$16(6.3)$

$31-40 \%$

$11(4.4)$

$41-50 \%$

$14(5.6)$

$51-60 \%$

$17(6.7)$

$16(6.3)$

$61-70 \%$

$38(15.1)$

$71-80 \%$

45 (17.9)

$81-90 \%$

$43(17.1)$

Characteristics of care delivery

Centre has its own MRI scan, $n(\%)^{\mathrm{b}}$

$228(90.5)$

Waiting time for MRI scan, $n(\%)$

$$
\begin{aligned}
& \leq 2 \text { weeks } \\
& >2 \text { weeks }
\end{aligned}
$$

$120(49.0)$

Waiting time for arthroscopy, $n(\%)^{\mathrm{b}}$

$$
\leq 2 \text { weeks }
$$

$>2$ weeks

$185(75.5)$

Implementation of $\mathrm{CW}$ recommendation regarding MRI/arthroscopy, $n$ (yes), \%

MRI, $n(\%)$

$208(82.5)$

$n=252$

${ }^{\mathrm{a}} n=244$

$\mathrm{b}_{n}=245$ 
Table 3 Presence factors influencing the implementation of CW recommendation for MRI and/or arthroscopy reported by patients $(n=116)$

\begin{tabular}{|c|c|}
\hline & Agree $n(\%)$ \\
\hline \multicolumn{2}{|l|}{ Individual professional } \\
\hline Orthopaedic surgeon asked which treatments the patient previously received for his/her knee complaints & $89(76.7)$ \\
\hline Orthopaedic surgeon listened well to patient's wishes & $89(76.7)$ \\
\hline Orthopaedic surgeon thought along with patient & $86(74.1)$ \\
\hline $\begin{array}{l}\text { Orthopaedic surgeon takes time to explain benefits and drawbacks of treatment options (medication, physical therapy or arthros- } \\
\text { copy) }\end{array}$ & $81(69.8)$ \\
\hline Orthopaedic surgeon explained the added value of MRI & $60(51.7)$ \\
\hline Orthopaedic surgeon explained the benefits and drawbacks of an arthroscopy & $60(51.7)$ \\
\hline Orthopaedic surgeon preferred an arthroscopy & $47(40.5)$ \\
\hline \multicolumn{2}{|l|}{ Patient } \\
\hline Physical activity was difficult because of pain & $97(83.6)$ \\
\hline Patient searched for information before visiting the orthopaedic surgeon & $73(62.9)$ \\
\hline Patient wanted an arthroscopy only if it was the last treatment option & $55(47.4)$ \\
\hline Patient expected to undergo an MRI scan before the consult with the orthopaedic surgeon & $37(31.9)$ \\
\hline Patient expected to undergo an arthroscopy prior to the consult with the orthopaedic surgeon & $39(33.6)$ \\
\hline Patient preferred to undergo an MRI scan during the consult with the orthopaedic surgeon & $54(46.6)$ \\
\hline Patient preferred to undergo an arthroscopy during the consult with the orthopaedic surgeon & $52(44.8)$ \\
\hline Patient previously had negative experiences with physical therapy & $15(12.9)$ \\
\hline \multicolumn{2}{|l|}{ In a situation in which different treatment options have approximately the same results: } \\
\hline$\ldots$ patient prefers to decide about the treatment him/herself (active) & $35(30.2)$ \\
\hline ... patient prefers to decide about the treatment together with the orthopaedic surgeon (shared) & $61(52.6)$ \\
\hline ... patient prefers to let the orthopaedic surgeon decide about the treatment (passive) & $20(17.2)$ \\
\hline \multicolumn{2}{|l|}{ In the situation of the consult of the patient with his/her orthopaedic surgeon: } \\
\hline ... patient decided about the treatment him/herself (active) & $30(25.9)$ \\
\hline ... patient decided about the treatment together with the orthopaedic surgeon (shared) & $41(35.3)$ \\
\hline ... patient let the orthopaedic surgeon decide about the treatment (passive) & $45(38.8)$ \\
\hline \multicolumn{2}{|l|}{ Social context } \\
\hline Good consultation between orthopaedic surgeon and physical therapist $\mathrm{t}^{\mathrm{a}}$ & $17(29.3)$ \\
\hline People in patient's environment recommended an MRI scan & $33(28.4)$ \\
\hline People in patient's environment had good experiences with arthroscopy & $48(41.4)$ \\
\hline People in patient's environment stimulated to keep on moving despite pain & $75(64.7)$ \\
\hline \multicolumn{2}{|l|}{ Organisational context } \\
\hline $\begin{array}{l}\text { Sufficient time for the orthopaedic surgeon to explain all treatment options (medication, physical therapy or arthroscopy), } \\
\text { including benefits and drawbacks }\end{array}$ & $80(69.0)$ \\
\hline Good contact with physical therapist helped patient to carry on with non-surgical therapy ${ }^{\mathrm{b}}$ & $64(90.1)$ \\
\hline Good guidance of the physical therapist helped the patient withstand the duration of the non-surgical therapy ${ }^{b}$ & $64(90.1)$ \\
\hline \multicolumn{2}{|l|}{ Economic and political context } \\
\hline Additional payment for physical therapy not (fully) covered by insurance & $99(85.3)$ \\
\hline Patient preferred an arthroscopy because physical therapy was not covered by insurance & $4(3.4)$ \\
\hline
\end{tabular}

${ }^{\mathrm{a}}$ Question answered by 58 of the 116 participants $(n=58)$

${ }^{\mathrm{b}}$ Question answered by 71 of the 116 participants $(n=71)$ 
Table 4 Influencing factors, background characteristics and received care reported by patients for implementation of CW recommendations ( $n=116)$ (univariate and multivariate analyses)

\begin{tabular}{|c|c|c|c|c|}
\hline & \multicolumn{2}{|l|}{ Univariate analyses } & \multicolumn{2}{|l|}{ Multivariate analyses } \\
\hline & $\begin{array}{l}\text { Implementation of CW } \\
\text { MRI recommendation } \\
\text { OR }(95 \% \mathrm{CI})\end{array}$ & $\begin{array}{l}\text { Implementation of CW } \\
\text { arthroscopy recommenda- } \\
\text { tion } \\
\text { OR }(95 \% \mathrm{CI})\end{array}$ & $\begin{array}{l}\text { Implementation of CW } \\
\text { MRI recommendation } \\
\text { OR }(95 \% \mathrm{CI})\end{array}$ & $\begin{array}{l}\text { Implementation of CW } \\
\text { arthroscopy recommen- } \\
\text { dation } \\
\text { OR }(95 \% \mathrm{CI})\end{array}$ \\
\hline \multicolumn{5}{|l|}{$\begin{array}{l}\text { Factors influencing the implementa- } \\
\text { tion of the } \mathrm{CW} \text { recommendations }\end{array}$} \\
\hline \multicolumn{5}{|l|}{ Individual professional } \\
\hline $\begin{array}{l}\text { Orthopaedic surgeon asked which } \\
\text { treatments the patient previ- } \\
\text { ously received for his/her knee } \\
\text { complaints }\end{array}$ & $1.18(0.48-2.92)(+)$ & $0.61(0.26-1.47)(-)$ & $\mathrm{x}$ & $\mathrm{x}$ \\
\hline $\begin{array}{l}\text { Orthopaedic surgeon listened well } \\
\text { to patient's wishes }\end{array}$ & $0.95(0.39-2.33)(-)$ & $0.91(0.38-2.15)(-)$ & $\mathrm{x}$ & $\mathrm{x}$ \\
\hline $\begin{array}{l}\text { Orthopaedic surgeon thought along } \\
\text { with the patient }\end{array}$ & $0.67(0.29-1.56)(-)$ & $1.00(0.44-2.30)$ & $\mathrm{x}$ & $\mathrm{x}$ \\
\hline $\begin{array}{l}\text { Orthopaedic surgeon takes time to } \\
\text { explain benefits and drawbacks } \\
\text { of treatment options (medication, } \\
\text { physical therapy, or arthroscopy) }\end{array}$ & $\mathrm{x}$ & $0.92(0.42-2.04)(-)$ & $\mathrm{x}$ & $\mathrm{x}$ \\
\hline $\begin{array}{l}\text { Orthopaedic surgeon explained the } \\
\text { added value of an MRI }\end{array}$ & $0.15(0.06-0.36)(-)$ & $\mathrm{x}$ & $0.18(0.07-0.47)(-)$ & $\mathrm{x}$ \\
\hline $\begin{array}{l}\text { Orthopaedic surgeon explained } \\
\text { the benefits and drawbacks of an } \\
\text { arthroscopy }\end{array}$ & $\mathrm{x}$ & $0.30(0.14-0.64)(-)$ & $\mathrm{x}$ & $0.61(0.09-3.94)(-)$ \\
\hline $\begin{array}{l}\text { Orthopaedic surgeon preferred an } \\
\text { arthroscopy }\end{array}$ & $\mathrm{x}$ & $0.02(0.01-0.06)(-)$ & $\mathrm{x}$ & $0.03(0.00-0.22)(-)$ \\
\hline \multicolumn{5}{|l|}{ Patient } \\
\hline $\begin{array}{l}\text { Patient expected to undergo an } \\
\text { MRI scan previous to the consult } \\
\text { with the orthopaedic surgeon }\end{array}$ & $0.45(0.19-1.07)(-)$ & $\mathrm{x}$ & $1.31(0.35-4.90)(+)$ & $\mathrm{x}$ \\
\hline $\begin{array}{l}\text { Patient expected to undergo an } \\
\text { arthroscopy previous to the con- } \\
\text { sult with the orthopaedic surgeon }\end{array}$ & $\mathrm{x}$ & $0.30(0.13-0.68)(-)$ & $\mathrm{x}$ & $4.88(0.36-65.71)(+)$ \\
\hline $\begin{array}{l}\text { Patient preferred to undergo an } \\
\text { MRI scan during the consult with } \\
\text { the orthopaedic surgeon }\end{array}$ & $0.21(0.09-0.50)(-)$ & $\mathrm{x}$ & $0.27(0.08-0.92)(-)$ & $\mathrm{x}$ \\
\hline $\begin{array}{l}\text { Patient preferred to undergo an } \\
\text { arthroscopy during the consult } \\
\text { with the orthopaedic surgeon }\end{array}$ & $\mathrm{x}$ & $0.12(0.05-0.27)(-)$ & $\mathrm{x}$ & $0.24(0.04-1.65)(-)$ \\
\hline $\begin{array}{l}\text { Physical activity was difficult } \\
\text { because of pain }\end{array}$ & $1.28(0.45-3.66)(+)$ & $0.88(0.33-2.36)(-)$ & $\mathrm{x}$ & $\mathrm{x}$ \\
\hline $\begin{array}{l}\text { Patient searched for information } \\
\text { previous to the visit to the ortho- } \\
\text { paedic surgeon }\end{array}$ & $0.42(0.19-0.93)(-)$ & $1.25(0.59-2.66)(+)$ & $0.84(0.31-2.28)(-)$ & $\mathrm{x}$ \\
\hline $\begin{array}{l}\text { Patient wanted an arthroscopy only } \\
\text { if it was the last treatment option }\end{array}$ & $\mathrm{x}$ & $0.81(0.39-1.69)(-)$ & $\mathrm{x}$ & $\mathrm{x}$ \\
\hline $\begin{array}{l}\text { Patient previously had negative } \\
\text { experiences with physical therapy }\end{array}$ & $0.60(0.18-2.03)(-)$ & $1.17(0.39-3.46)(+)$ & $\mathrm{x}$ & $\mathrm{x}$ \\
\hline \multicolumn{5}{|l|}{$\begin{array}{l}\text { In a situation in which different } \\
\text { treatment options have approxi- } \\
\text { mately the same results...: }\end{array}$} \\
\hline $\begin{array}{l}\text {... patient prefers to decide about } \\
\text { the treatment him/herself }\end{array}$ & $0.60(0.19-1.91)(-)$ & $1.78(0.58-5.43)(+)$ & $\mathrm{x}$ & $\mathrm{x}$ \\
\hline
\end{tabular}


Table 4 (continued)

\begin{tabular}{|c|c|c|c|c|}
\hline & \multicolumn{2}{|l|}{ Univariate analyses } & \multicolumn{2}{|l|}{ Multivariate analyses } \\
\hline & $\begin{array}{l}\text { Implementation of CW } \\
\text { MRI recommendation } \\
\text { OR }(95 \% \mathrm{CI})\end{array}$ & $\begin{array}{l}\text { Implementation of CW } \\
\text { arthroscopy recommenda- } \\
\text { tion } \\
\text { OR }(95 \% \mathrm{CI})\end{array}$ & $\begin{array}{l}\text { Implementation of CW } \\
\text { MRI recommendation } \\
\text { OR }(95 \% \mathrm{CI})\end{array}$ & $\begin{array}{l}\text { Implementation of } \mathrm{CW} \\
\text { arthroscopy recommen- } \\
\text { dation } \\
\text { OR }(95 \% \mathrm{CI})\end{array}$ \\
\hline $\begin{array}{l}\ldots \text { patient prefers to decide about } \\
\text { the treatment together with the } \\
\text { orthopaedic surgeon }\end{array}$ & $0.97(0.35-2.73)(-)$ & $1.55(0.56-4.32)(+)$ & $\mathrm{x}$ & $\mathrm{x}$ \\
\hline $\begin{array}{l}\text {... patient prefers to let the ortho- } \\
\text { paedic surgeon decide about the } \\
\text { treatment }\end{array}$ & Reference category & Reference category & $\mathrm{x}$ & $\mathrm{x}$ \\
\hline \multicolumn{5}{|l|}{$\begin{array}{l}\text { In the situation of the consult of the } \\
\text { patient with his/her orthopaedic } \\
\text { surgeon: }\end{array}$} \\
\hline $\begin{array}{l}\text {.. patient decided about the treat- } \\
\text { ment him/herself }\end{array}$ & $0.91(0.34-2.40)(-)$ & $1.97(0.77-5.08)(+)$ & $\mathrm{x}$ & $\mathrm{x}$ \\
\hline $\begin{array}{l}\text {.. patient decided about the } \\
\text { treatment together with the } \\
\text { orthopaedic surgeon }\end{array}$ & $1.16(0.48-2.78)(+)$ & $0.89(0.38-2.09)(-)$ & $\mathrm{x}$ & $\mathrm{x}$ \\
\hline $\begin{array}{l}\ldots \text { patient let the orthopaedic sur- } \\
\text { geon decide about the treatment }\end{array}$ & Reference category & Reference category & $\mathrm{x}$ & $\mathrm{x}$ \\
\hline \multicolumn{5}{|l|}{ Social context } \\
\hline $\begin{array}{l}\text { Good consultation between } \\
\text { orthopaedic surgeon and physical } \\
\text { therapist }^{\mathrm{a}}\end{array}$ & $\mathrm{x}$ & $0.80(0.26-2.48)(-)$ & $\mathrm{x}$ & $\mathrm{x}$ \\
\hline $\begin{array}{l}\text { People in patients' environment } \\
\text { recommended an MRI scan }\end{array}$ & $0.37(0.14-0.95)(-)$ & $\mathrm{x}$ & $0.64(0.19-2.12)(-)$ & $\mathrm{x}$ \\
\hline $\begin{array}{l}\text { People in patients' environment had } \\
\text { good experiences with arthros- } \\
\text { copy }\end{array}$ & $\mathrm{x}$ & $0.13(0.06-0.31)(-)$ & $\mathrm{x}$ & $0.03(0.00-0.39)(-)$ \\
\hline $\begin{array}{l}\text { People in patients' environment } \\
\text { stimulated to keep on moving } \\
\text { despite the pain }\end{array}$ & $1.36(0.61-3.04)(+)$ & $1.99(0.92-4.32)(+)$ & $\mathrm{x}$ & $2.77(0.24-31.44)(+)$ \\
\hline \multicolumn{5}{|l|}{ Organisational context } \\
\hline $\begin{array}{l}\text { Sufficient time for the orthopaedic } \\
\text { surgeon to explain all treatment } \\
\text { options (medication, physical } \\
\text { therapy or arthroscopy), including } \\
\text { risks and benefits }\end{array}$ & $\mathrm{x}$ & $1.18(0.54-2.58)(+)$ & $\mathrm{x}$ & $\mathrm{x}$ \\
\hline $\begin{array}{l}\text { Good contact with physical thera- } \\
\text { pist helped the patient to carry on } \\
\text { with non-surgical therapy }{ }^{b}(-)\end{array}$ & $\mathrm{x}$ & $8.22(0.94-72.33)(+)$ & $\mathrm{x}$ & $7.69(0.01-5090.47)(+)$ \\
\hline $\begin{array}{l}\text { Good guidance of the physical } \\
\text { therapist helped the patient to } \\
\text { withstand the duration of the non- } \\
\text { surgical therapy }\end{array}$ & $\mathrm{x}$ & $8.22(0.94-72.33)(+)$ & $\mathrm{x}$ & $5.95(0.01-3504.06)(+)$ \\
\hline \multicolumn{5}{|l|}{ Economic and political context } \\
\hline $\begin{array}{l}\text { Additional payment for physical } \\
\text { therapy (fully) covered by insur- } \\
\text { ance }\end{array}$ & $0.78(0.27-2.23)(-)$ & $1.15(0.41-3.22)(+)$ & $\mathrm{x}$ & $\mathrm{x}$ \\
\hline $\begin{array}{l}\text { Patient preferred an arthroscopy } \\
\text { because physical therapy was not } \\
\text { covered by insurance }\end{array}$ & $1.80(0.24-13.27)(+)$ & $1.00(0.14-7.35)$ & $\mathrm{x}$ & $\mathrm{x}$ \\
\hline \multicolumn{5}{|l|}{ Background characteristics } \\
\hline Age & $1.09(1.03-1.15))(+)$ & $0.98(0.94-1.03)(-)$ & $1.07(1.01-1.14)(+)$ & $\mathrm{x}$ \\
\hline Gender & $0.90(0.41-1.94)(-)$ & $1.94(0.91-4.13)(+)$ & $\mathrm{x}$ & $2.28(0.31-16.82)(+)$ \\
\hline Province of residence & & & & \\
\hline
\end{tabular}

\begin{tabular}{|c|c|c|c|c|}
\hline & \multicolumn{2}{|l|}{ Univariate analyses } & \multicolumn{2}{|l|}{ Multivariate analyses } \\
\hline & $\begin{array}{l}\text { Implementation of CW } \\
\text { MRI recommendation } \\
\text { OR }(95 \% \mathrm{CI})\end{array}$ & $\begin{array}{l}\text { Implementation of CW } \\
\text { arthroscopy recommenda- } \\
\text { tion } \\
\text { OR }(95 \% \mathrm{CI})\end{array}$ & $\begin{array}{l}\text { Implementation of CW } \\
\text { MRI recommendation } \\
\text { OR }(95 \% \mathrm{CI})\end{array}$ & $\begin{array}{l}\text { Implementation of } \mathrm{CW} \\
\text { arthroscopy recommen- } \\
\text { dation } \\
\text { OR }(95 \% \mathrm{CI})\end{array}$ \\
\hline $\begin{array}{l}\ldots \text { patient prefers to decide about } \\
\text { the treatment together with the } \\
\text { orthopaedic surgeon }\end{array}$ & $0.97(0.35-2.73)(-)$ & $1.55(0.56-4.32)(+)$ & $\mathrm{x}$ & $\mathrm{x}$ \\
\hline $\begin{array}{l}\text {... patient prefers to let the ortho- } \\
\text { paedic surgeon decide about the } \\
\text { treatment }\end{array}$ & Reference category & Reference category & $\mathrm{x}$ & $\mathrm{x}$ \\
\hline \multicolumn{5}{|l|}{$\begin{array}{l}\text { In the situation of the consult of the } \\
\text { patient with his/her orthopaedic } \\
\text { surgeon: }\end{array}$} \\
\hline $\begin{array}{l}\text {.. patient decided about the treat- } \\
\text { ment him/herself }\end{array}$ & $0.91(0.34-2.40)(-)$ & $1.97(0.77-5.08)(+)$ & $\mathrm{x}$ & $\mathrm{x}$ \\
\hline $\begin{array}{l}\text {.. patient decided about the } \\
\text { treatment together with the } \\
\text { orthopaedic surgeon }\end{array}$ & $1.16(0.48-2.78)(+)$ & $0.89(0.38-2.09)(-)$ & $\mathrm{x}$ & $\mathrm{x}$ \\
\hline $\begin{array}{l}\ldots \text { patient let the orthopaedic sur- } \\
\text { geon decide about the treatment }\end{array}$ & Reference category & Reference category & $\mathrm{x}$ & $\mathrm{x}$ \\
\hline \multicolumn{5}{|l|}{ Social context } \\
\hline $\begin{array}{l}\text { Good consultation between } \\
\text { orthopaedic surgeon and physical } \\
\text { therapist }^{\mathrm{a}}\end{array}$ & $\mathrm{x}$ & $0.80(0.26-2.48)(-)$ & $\mathrm{x}$ & $\mathrm{x}$ \\
\hline $\begin{array}{l}\text { People in patients' environment } \\
\text { recommended an MRI scan }\end{array}$ & $0.37(0.14-0.95)(-)$ & $\mathrm{x}$ & $0.64(0.19-2.12)(-)$ & $\mathrm{x}$ \\
\hline $\begin{array}{l}\text { People in patients' environment had } \\
\text { good experiences with arthros- } \\
\text { copy }\end{array}$ & $\mathrm{x}$ & $0.13(0.06-0.31)(-)$ & $\mathrm{x}$ & $0.03(0.00-0.39)(-)$ \\
\hline $\begin{array}{l}\text { People in patients' environment } \\
\text { stimulated to keep on moving } \\
\text { despite the pain }\end{array}$ & $1.36(0.61-3.04)(+)$ & $1.99(0.92-4.32)(+)$ & $\mathrm{x}$ & $2.77(0.24-31.44)(+)$ \\
\hline \multicolumn{5}{|l|}{ Organisational context } \\
\hline $\begin{array}{l}\text { Sufficient time for the orthopaedic } \\
\text { surgeon to explain all treatment } \\
\text { options (medication, physical } \\
\text { therapy or arthroscopy), including } \\
\text { risks and benefits }\end{array}$ & $\mathrm{x}$ & $1.18(0.54-2.58)(+)$ & $\mathrm{x}$ & $\mathrm{x}$ \\
\hline $\begin{array}{l}\text { Good contact with physical thera- } \\
\text { pist helped the patient to carry on } \\
\text { with non-surgical therapy }{ }^{b}(-)\end{array}$ & $\mathrm{x}$ & $8.22(0.94-72.33)(+)$ & $\mathrm{x}$ & $7.69(0.01-5090.47)(+)$ \\
\hline $\begin{array}{l}\text { Good guidance of the physical } \\
\text { therapist helped the patient to } \\
\text { withstand the duration of the non- } \\
\text { surgical therapy }\end{array}$ & $\mathrm{x}$ & $8.22(0.94-72.33)(+)$ & $\mathrm{x}$ & $5.95(0.01-3504.06)(+)$ \\
\hline \multicolumn{5}{|l|}{ Economic and political context } \\
\hline $\begin{array}{l}\text { Additional payment for physical } \\
\text { therapy (fully) covered by insur- } \\
\text { ance }\end{array}$ & $0.78(0.27-2.23)(-)$ & $1.15(0.41-3.22)(+)$ & $\mathrm{x}$ & $\mathrm{x}$ \\
\hline $\begin{array}{l}\text { Patient preferred an arthroscopy } \\
\text { because physical therapy was not } \\
\text { covered by insurance }\end{array}$ & $1.80(0.24-13.27)(+)$ & $1.00(0.14-7.35)$ & $\mathrm{x}$ & $\mathrm{x}$ \\
\hline \multicolumn{5}{|l|}{ Background characteristics } \\
\hline Age & $1.09(1.03-1.15))(+)$ & $0.98(0.94-1.03)(-)$ & $1.07(1.01-1.14)(+)$ & $\mathrm{x}$ \\
\hline Gender & $0.90(0.41-1.94)(-)$ & $1.94(0.91-4.13)(+)$ & $\mathrm{x}$ & $2.28(0.31-16.82)(+)$ \\
\hline Province of residence & & & & \\
\hline
\end{tabular}

Multivariate analyses

Implementation of $\mathrm{CW}$ Implementation of $\mathrm{CW}$

MRI recommendation arthroscopy recommen-

OR $(95 \% \mathrm{CI}) \quad$ dation

OR $(95 \% \mathrm{CI})$ 
Table 4 (continued)

\begin{tabular}{|c|c|c|c|c|}
\hline & \multicolumn{2}{|l|}{ Univariate analyses } & \multicolumn{2}{|l|}{ Multivariate analyses } \\
\hline & $\begin{array}{l}\text { Implementation of CW } \\
\text { MRI recommendation } \\
\text { OR }(95 \% \mathrm{CI})\end{array}$ & $\begin{array}{l}\text { Implementation of CW } \\
\text { arthroscopy recommenda- } \\
\text { tion } \\
\text { OR }(95 \% \mathrm{CI})\end{array}$ & $\begin{array}{l}\text { Implementation of CW } \\
\text { MRI recommendation } \\
\text { OR }(95 \% \mathrm{CI})\end{array}$ & $\begin{array}{l}\text { Implementation of CW } \\
\text { arthroscopy recommen- } \\
\text { dation } \\
\text { OR }(95 \% \mathrm{CI})\end{array}$ \\
\hline North & $0.66(0.28-1.55)(-)$ & $0.94(0.43-2.09)(-)$ & $\mathrm{x}$ & $\mathrm{x}$ \\
\hline Middle & Reference category & Reference category & $\mathrm{x}$ & $\mathrm{x}$ \\
\hline South & $1.61(0.43-6.12)(+)$ & $0.63(0.16-2.43)(-)$ & $\mathrm{x}$ & $\mathrm{x}$ \\
\hline \multicolumn{5}{|l|}{ Level of education } \\
\hline Basic & $2.32(0.50-10.69)(+)$ & $2.69(0.50-14.51)(+)$ & $3.45(0.57-20.88)(+)$ & $\mathrm{x}$ \\
\hline Intermediate & $0.50(0.22-1.13)(-)$ & $0.69(0.32-1.47)(-)$ & $0.66(0.25-1.77)(-)$ & $\mathrm{x}$ \\
\hline High & Reference category & Reference category & Constant factor & $\mathrm{x}$ \\
\hline $\begin{array}{l}\text { Pain before consult with orthopae- } \\
\text { dic surgeon }\end{array}$ & $0.97(0.81-1.15)(-)$ & $0.94(0.80-1.12)(-)$ & $\mathrm{x}$ & $\mathrm{x}$ \\
\hline $\begin{array}{l}\text { Diagnosis of orthopaedic surgeon } \\
\text { was a locked knee } \mathrm{e}^{\mathrm{c}}\end{array}$ & $2.63(0.50-13.72)(+)$ & $\mathrm{x}$ & $\mathrm{x}$ & $\mathrm{x}$ \\
\hline \multicolumn{5}{|l|}{ Received care } \\
\hline $\begin{array}{l}\text { Time between start of knee com- } \\
\text { plaints and the consult with the } \\
\text { general practitioner }{ }^{\mathrm{d}}\end{array}$ & $0.77(0.32-1.84)(-)$ & $0.91(0.40-2.07)(-)$ & $\mathrm{x}$ & $\mathrm{x}$ \\
\hline $\begin{array}{l}\text { Time between consult with the } \\
\text { general practitioner and consult } \\
\text { with orthopaedic surgeon }{ }^{\mathrm{e}}\end{array}$ & $0.81(0.30-2.19)(-)$ & $0.88(0.33-2.35)(-)$ & $\mathrm{x}$ & $\mathrm{x}$ \\
\hline
\end{tabular}

OR $(95 \% \mathrm{CI})=$ odds ratio $(95 \%$ confidence interval $),(-)$ barrier, $\mathrm{OR}<1,(+)$ facilitator, $\mathrm{OR}>1$. In bold: $p$ values $\leq 0.05, n=116$

${ }^{\mathrm{a}} n=58$

$\mathrm{b}_{n=71}$

${ }^{\mathrm{c}} n=52$

${ }^{\mathrm{d}} n=92$

$\mathrm{e}_{n=103}$

Previous studies were limited in only presenting the clinician perspective and mentioned clinician beliefs in the effectiveness of arthroscopic surgery [24, 28], clinicians' need to meet patient expectations [12], perverse financial incentives [24, 28], fragmented clinical decision pathways [24] and insurance coverage [32] as possible barriers for implementation of $\mathrm{CW}$ recommendations regarding MRI and arthroscopy in degenerative knee disease. Our study results confirm that clinician beliefs hamper implementation, but perverse financial incentives for clinicians/hospitals, fragmented clinical decision pathways, and insurance coverage were not identified as barriers. Possibly, this can be explained by a different health-care system in which the studies are performed. In this study only $7 \%$ of the orthopaedic surgeons felt pressure to perform MRIs and arthroscopies because of production agreements and $75 \%$ of the orthopaedic surgeons reported that they were able to make clear agreements with GPs, physical therapists and dieticians about care delivery (Table 5). Furthermore, in this study $85 \%$ of the patients have reported that they have additional coverage for physical therapy treatment (Table 1).

Previous studies also showed that clinicians felt $\mathrm{CW}$ recommendations were hard to accept for patients [46], were worried about malpractice claims and did not have enough time to discuss the risks and benefits of imaging with the patient [36]. Around $70 \%$ of the orthopaedic surgeons reported in this survey that they thought patients had difficulties in accepting the $\mathrm{CW}$ recommendations (Table 5), but these were not independently associated with implementation in multivariate regression analyses. In addition, fear of malpractice claims and lack of time to discuss risks and benefits of imaging with the patients were also not found to hamper implementation: less than $11 \%$ of the orthopaedic surgeons felt they needed to request an MRI or perform an arthroscopy for medicolegal substantiation (Table 5). Sixty-six percent of orthopaedic surgeons reported they had enough time to explain treatment options to patients (Table 5) and $69 \%$ of the patients felt that their orthopaedic surgeon spent sufficient time to explain treatment options including risks and benefits (Table 3). This underlines the importance of assessment of factors influencing the implementation of every $\mathrm{CW}$ recommendation for different countries and also to include both the clinician and the patient perspective.

That the implementation of $\mathrm{CW}$ recommendations can also be influenced by patients was shown by this study, in addition to other studies. While previous studies regarding 
Table 5 Orthopaedic surgeons' agreement with factors influencing the implementation of the CW recommendation regarding MRI and/or arthroscopy $(n=252)$

Individual professional

Orthopaedic surgeon asks about previously received non-surgical treatments (physical therapy, medication, nutritional advice when BMI $>25$ and lifestyle advice)

Orthopaedic surgeon prescribes one or more non-surgical treatments (physical therapy, medication, nutritional advice when BMI > 25 and lifestyle advice) if patient did not receive all non-surgical treatment care yet

Belief in effectivity of non-surgical treatment strategy (physical therapy, medication, nutritional advice when BMI $>25$ and lifestyle advice) for knee complaints of patients $\geq 50$ years

Fully familiar with the $\mathrm{CW}$ recommendation for MRI

Agrees with the CW recommendation for MRI

Higher valuation of own experience with MRI than of existing evidence

Belief in value of MRI over fixed flexion view

Fully familiar with the CW recommendation for arthroscopy

$109(43.3)$

$248(98.4)$

Agrees with the CW recommendation for arthroscopy

$234(92.9)$

$73(29.0)$

Higher valuation of own experience with arthroscopy than of existing evidence

Belief in value of arthroscop
complications and risks

Important to perform arthroscopy as soon as possible for patients $\geq 50$ years with knee complaints, without 'locked knee' complaints

Actively searches for latest knowledge about evidence and guidelines for diagnosis/treatment of knee complaints

Orthopaedic surgeon wants to meet patients' expectations ${ }^{\mathrm{a}}$

Orthopaedic surgeon is able to clarify to the patient whether an MRI scan is necessary, even if the patient has a contradictory opinion at first ${ }^{\mathrm{a}}$

Orthopaedic surgeon is able to clarify to the patient whether an arthroscopy is necessary, even if the patient has a contradictory opinion at first ${ }^{\mathrm{a}}$

Patient

Orthopaedic surgeon notices that patients are well prepared for the consult by gaining knowledge

Patients' level of knowledge is sufficient to make a shared decision about treatment

Patients $\geq 50$ years with knee complaints have certain expectations about diagnostics and treatment when they come to the consult $^{\mathrm{a}}$

Most patients find it difficult that the CW recommendation for MRI also applies to them ${ }^{\mathrm{a}}$

Most patients find it difficult that the CW recommendation for arthroscopy also applies to them ${ }^{\mathrm{a}}$

Social context

Colleagues all follow the CW recommendation for MRI and arthroscopy ${ }^{\mathrm{b}}$

Colleagues tell me when I do not follow the guidelines ${ }^{\mathrm{b}}$

Colleagues are in favour of non-surgical treatments (physical therapy, medication, nutritional advice and lifestyle advice) ${ }^{\mathrm{b}}$

Organisational context

Able to make clear arrangements with primary care (GP, physical therapist, dietician)

Good feedback from primary care (GP, physical therapist, dietician) to orthopaedic surgeon about patient progress

Enough time to explain to the patient which diagnosis and treatment options are applicable to the patient's situation ${ }^{\mathrm{a}}$

Pressure of production arthroscopy ${ }^{\mathrm{b}}$

Economic and political context

Financial reasons determine patient preference (arthroscopy more often covered by insurance than non-surgical treatment ${ }^{\mathrm{a}}$ )

$n=252$

${ }^{\mathrm{a}} n=247$

${ }^{\mathrm{b}} n=245$ 
Table 6 Influencing factors and background characteristics reported by orthopaedic surgeons for the implementation of the CW recommendations ( $n=252)$ (univariate and multivariate analyses)

\begin{tabular}{|c|c|c|c|c|}
\hline & \multicolumn{2}{|l|}{ Univariate analyses } & \multicolumn{2}{|l|}{ Multivariate analyses } \\
\hline & $\begin{array}{l}\text { Acts according to CW } \\
\text { MRI recommendation } \\
\text { OR }(95 \% \mathrm{CI})\end{array}$ & $\begin{array}{l}\text { Acts according to arthros- } \\
\text { copy CW recommendation } \\
\text { OR }(95 \% \text { CI })\end{array}$ & $\begin{array}{l}\text { Acts according to CW } \\
\text { MRI recommendation } \\
\text { OR }(95 \% \mathrm{CI})\end{array}$ & $\begin{array}{l}\text { Acts according to arthroscopy } \\
\text { CW recommendation OR } \\
(95 \% \text { CI) }\end{array}$ \\
\hline \multicolumn{5}{|l|}{$\begin{array}{l}\text { Factors influencing the imple- } \\
\text { mentation of CW recom- } \\
\text { mendations }\end{array}$} \\
\hline \multicolumn{5}{|l|}{ Individual professional } \\
\hline $\begin{array}{l}\text { Orthopaedic surgeon asks } \\
\text { about previously received } \\
\text { non-surgical treatments }\end{array}$ & $1.39(0.14-13.65)(+)$ & $x^{d}$ & $\mathrm{x}$ & $\mathrm{x}$ \\
\hline $\begin{array}{l}\text { Orthopaedic surgeon uses } \\
\text { step-by-step treatment } \\
\text { strategy }\end{array}$ & $2.17(0.63-7.51)(+)$ & $2.50(0.72-8.70)(+)$ & $\mathrm{x}$ & $\mathrm{x}$ \\
\hline $\begin{array}{l}\text { Belief in effectivity of non- } \\
\text { surgical treatment strategy }\end{array}$ & $2.91(1.07-7.95)(+)$ & $2.58(0.91-7.29)(+)$ & $0.96(0.22-4.27)(-)$ & $0.31(0.03-3.10)(-)$ \\
\hline $\begin{array}{l}\text { Knowledge about the CW } \\
\text { recommendation for MRI }\end{array}$ & $2.09(0.19-23.57)(+)$ & $\mathrm{x}$ & $\mathrm{x}$ & $\mathrm{x}$ \\
\hline $\begin{array}{l}\text { Agree with the } \mathrm{CW} \text { recom- } \\
\text { mendation for MRI }\end{array}$ & $14.88(5.72-38.70)(+)$ & $\mathrm{x}$ & $12.10(3.51-41.64)(+)$ & $\mathrm{x}$ \\
\hline $\begin{array}{l}\text { Higher valuation of own } \\
\text { experience with MRI than } \\
\text { of existing evidence }\end{array}$ & $0.27(0.14-0.51)(-)$ & $\mathrm{x}$ & $0.41(0.19-0.88)(-)$ & $\mathrm{x}$ \\
\hline $\begin{array}{l}\text { Belief in value of MRI over } \\
\text { fixed flexion view }\end{array}$ & $0.36(0.19-0.69)(-)$ & $\mathrm{x}$ & $0.49(0.23-1.07)(-)$ & $\mathrm{x}$ \\
\hline $\begin{array}{l}\text { Orthopaedic surgeon actively } \\
\text { searches for latest knowledge } \\
\text { about evidence and guide- } \\
\text { lines for diagnosis/treatment } \\
\text { of knee complaints }\end{array}$ & $e^{2.46(1.24-4.91)(+)}$ & $2.64(1.30-5.37)(+)$ & $1.87(0.79-4.45)(+)$ & $3.28(1.19-9.08)(+)$ \\
\hline $\begin{array}{l}\text { Knowledge about the } \mathrm{CW} \\
\text { recommendation for } \\
\text { arthroscopy }\end{array}$ & $\mathrm{x}$ & $15.15(1.54-149.25)(+)$ & $\mathrm{x}$ & $58.17(2.63-1287.24)(+)$ \\
\hline $\begin{array}{l}\text { Agrees with the CW recom- } \\
\text { mendation for arthroscopy }\end{array}$ & $\mathrm{x}$ & $58.86(12.85-269.66)(+)$ & $\mathrm{x}$ & $37.45(5.39-260.24)(+)$ \\
\hline $\begin{array}{l}\text { Higher valuation of own } \\
\text { experience with arthroscopy } \\
\text { than of existing evidence }\end{array}$ & $\mathrm{x}$ & $0.14(0.07-0.28)(-)$ & $\mathrm{x}$ & $0.17(0.07-0.46)(-)$ \\
\hline $\begin{array}{l}\text { Belief in value of arthros- } \\
\text { copy despite possible } \\
\text { complications and risks }\end{array}$ & $\mathrm{x}$ & $0.10(0.05-0.22)(-)$ & $\mathrm{x}$ & $0.28(0.10-0.81)(-)$ \\
\hline $\begin{array}{l}\text { Important to perform arthros- } \\
\text { copy as soon as possible }\end{array}$ & & $0.84(0.09-7.73)(-)$ & $\mathrm{x}$ & $\mathrm{x}$ \\
\hline $\begin{array}{l}\text { Orthopaedic surgeon } \\
\text { wants to meet patients' } \\
\text { expectations }^{\mathrm{a}}\end{array}$ & $0.80(0.41-1.54)(-)$ & $1.20(0.62-2.34)(+)$ & $\mathrm{x}$ & $\mathrm{x}$ \\
\hline $\begin{array}{l}\text { Orthopaedic surgeon is able to } \\
\text { clarify to the patient whether } \\
\text { an MRI scan is necessary, } \\
\text { even if the patient has a con- } \\
\text { tradictory opinion at first }^{\mathrm{a}}\end{array}$ & $1.29(0.66-2.52)(+)$ & $\mathrm{x}$ & $\mathrm{x}$ & $\mathrm{x}$ \\
\hline $\begin{array}{l}\text { Orthopaedic surgeon is able } \\
\text { to clarify to the patient } \\
\text { whether an arthroscopy } \\
\text { is necessary, even if the } \\
\text { patient has a contradictory } \\
\text { opinion at first }^{\mathrm{a}}\end{array}$ & $\mathrm{x}$ & $1.29(0.62-2.72)(+)$ & $\mathrm{x}$ & $\mathrm{x}$ \\
\hline
\end{tabular}


Table 6 (continued)

\begin{tabular}{|c|c|c|c|c|}
\hline & \multicolumn{2}{|l|}{ Univariate analyses } & \multicolumn{2}{|l|}{ Multivariate analyses } \\
\hline & $\begin{array}{l}\text { Acts according to CW } \\
\text { MRI recommendation } \\
\text { OR }(95 \% \mathrm{CI})\end{array}$ & $\begin{array}{l}\text { Acts according to arthros- } \\
\text { copy CW recommendation } \\
\text { OR }(95 \% \mathrm{CI})\end{array}$ & $\begin{array}{l}\text { Acts according to CW } \\
\text { MRI recommendation } \\
\text { OR }(95 \% \mathrm{CI})\end{array}$ & $\begin{array}{l}\text { Acts according to arthroscopy } \\
\text { CW recommendation OR } \\
(95 \% \text { CI) }\end{array}$ \\
\hline \multicolumn{5}{|l|}{ Patient } \\
\hline $\begin{array}{l}\text { Orthopaedic surgeon notices } \\
\text { that patients are well } \\
\text { prepared for the consult by } \\
\text { gaining knowledge }\end{array}$ & $0.62(0.32-1.20)(-)$ & $0.64(0.32-1.30)(-)$ & $\mathrm{x}$ & $\mathrm{x}$ \\
\hline $\begin{array}{l}\text { Patients' level of knowledge is } \\
\text { sufficient to make a shared } \\
\text { decision about treatment }\end{array}$ & s0.55 (0.29-1.04) (-) & $1.00(0.50-2.00)$ & $0.38(0.17-0.88)(-)$ & $\mathrm{x}$ \\
\hline $\begin{array}{l}\text { Patients } \geq 50 \text { years with knee } \\
\text { complaints have certain } \\
\text { expectations about diag- } \\
\text { nostics and treatment when } \\
\text { they come to the consult }{ }^{\mathrm{a}}\end{array}$ & $0.76(0.16-3.57)(-)$ & $0.86(0.18-4.01)(-)$ & $\mathrm{x}$ & $\mathrm{x}$ \\
\hline $\begin{array}{l}\text { Most patients find it difficult } \\
\text { that the CW recommendation } \\
\text { for MRI also applies to them }\end{array}$ & $0.26(0.09-0.75)(-)$ & $\mathrm{x}$ & $0.34(0.10-1.16)(-)$ & $\mathrm{x}$ \\
\hline $\begin{array}{l}\text { Most patients find it difficult } \\
\text { that the CW recommenda- } \\
\text { tion for arthroscopy also } \\
\text { applies to them }{ }^{\mathrm{a}}\end{array}$ & $\mathrm{x}$ & $0.53(0.24-1.17)(-)$ & $\mathrm{x}$ & $\mathrm{x}$ \\
\hline \multicolumn{5}{|l|}{ Social context } \\
\hline $\begin{array}{l}\text { All colleagues follow the } \\
\text { CW recommendation for } \\
\text { MRI and arthroscopy }{ }^{b}\end{array}$ & $2.09(1.10-3.97)(+)$ & $4.79(2.37-9.69)(+)$ & $1.54(0.66-3.60)(+)$ & $2.51(0.94-6.70)(+)$ \\
\hline $\begin{array}{l}\text { Colleagues speak to me } \\
\text { when I do not follow the } \\
\text { guidelines }{ }^{b}\end{array}$ & $1.78(0.85-3.72)(+)$ & $1.79(0.84-3.81)(+)$ & $\mathrm{x}$ & $\mathrm{x}$ \\
\hline $\begin{array}{l}\text { Positive attitude of colleagues } \\
\text { towards non-surgical treat- } \\
\text { ments (physical therapy, } \\
\text { medication, nutritional } \\
\text { advice and lifestyle advice) }^{\mathrm{b}}\end{array}$ & $3.30(1.38-7.91)(+)$ & $1.99(0.77-5.11)(+)$ & $1.13(0.32-3.94)(+)$ & $\mathrm{x}$ \\
\hline \multicolumn{5}{|l|}{ Organisational context } \\
\hline $\begin{array}{l}\text { Orthopaedic surgeon is able } \\
\text { to make clear arrangements } \\
\text { with primary care (GP, } \\
\text { physical therapist, dietician) }\end{array}$ & $1.22(0.61-2.46)(+)$ & $1.68(0.83-3.38)(+)$ & $\mathrm{x}$ & $\mathrm{x}$ \\
\hline $\begin{array}{l}\text { Good feedback from pri- } \\
\text { mary care (GP, physical } \\
\text { therapist, dietician) to } \\
\text { orthopaedic surgeon about } \\
\text { patient's progress }\end{array}$ & $1.00(0.54-1.88)$ & $1.60(0.83-3.09)(+)$ & $\mathrm{x}$ & $\mathrm{x}$ \\
\hline $\begin{array}{l}\text { Enough time to keep knowl- } \\
\text { edge of guidelines about } \\
\text { diagnosis/treatment of } \\
\text { knee complaints up to date }\end{array}$ & $1.75(0.93-3.28)(+)$ & $0.81(0.41-1.61)(-)$ & $2.14(0.95-4.84)(+)$ & $\mathrm{x}$ \\
\hline $\begin{array}{l}\text { Enough time to explain the } \\
\text { patient which diagnosis and } \\
\text { treatment options are applica- } \\
\text { ble to the patients' situation }{ }^{\mathrm{a}}\end{array}$ & $1.03(0.52-2.00)(+)$ & $0.95(0.47-1.90)(-)$ & $\mathrm{x}$ & $\mathrm{x}$ \\
\hline Pressure of production $\mathrm{MRI}^{\mathrm{b}}$ & $1.84(0.41-8.36)(+)$ & $\mathrm{x}$ & $\mathrm{x}$ & $\mathrm{x}$ \\
\hline $\begin{array}{l}\text { Pressure of production } \\
\text { arthroscopy }\end{array}$ & $\mathrm{x}$ & $0.99(0.27-3.62)(-)$ & $\mathrm{x}$ & $\mathrm{x}$ \\
\hline Waiting time for MRI scan & $1.00(0.53-1.89)$ & $\mathrm{x}$ & $\mathrm{x}$ & $\mathrm{x}$ \\
\hline
\end{tabular}


Table 6 (continued)

\begin{tabular}{|c|c|c|c|c|}
\hline & \multicolumn{2}{|l|}{ Univariate analyses } & \multicolumn{2}{|l|}{ Multivariate analyses } \\
\hline & $\begin{array}{l}\text { Acts according to } \mathrm{CW} \\
\text { MRI recommendation } \\
\text { OR }(95 \% \mathrm{CI})\end{array}$ & $\begin{array}{l}\text { Acts according to arthros- } \\
\text { copy CW recommendation } \\
\text { OR }(95 \% \mathrm{CI})\end{array}$ & $\begin{array}{l}\text { Acts according to } \mathrm{CW} \\
\text { MRI recommendation } \\
\text { OR }(95 \% \mathrm{CI})\end{array}$ & $\begin{array}{l}\text { Acts according to arthroscopy } \\
\text { CW recommendation OR } \\
(95 \% \text { CI })\end{array}$ \\
\hline Waiting time for arthroscopy & $\mathrm{x}$ & $1.64(0.80-3.36)(+)$ & $\mathrm{x}$ & $\mathrm{x}$ \\
\hline \multicolumn{5}{|l|}{ Economic and political context } \\
\hline $\begin{array}{l}\text { Financial reasons determine } \\
\text { patient preference because } \\
\text { arthroscopy is more often } \\
\text { covered by insurance than } \\
\text { non-surgical treatment }{ }^{\mathrm{a}}\end{array}$ & $\mathrm{x}$ & $1.88(0.88-4.03)(+)$ & $\mathrm{x}$ & $\mathrm{x}$ \\
\hline $\begin{array}{l}\text { Medicolegal substantiation } \\
\text { to follow the CW recom- } \\
\text { mendation for MRI }{ }^{\mathrm{b}}\end{array}$ & $0.64(0.25-1.62)(-)$ & $\mathrm{x}$ & $\mathrm{x}$ & $\mathrm{x}$ \\
\hline $\begin{array}{l}\text { Medicolegal substantiation to } \\
\text { follow the CW recommen- } \\
\text { dation for arthroscopy }\end{array}$ & $\mathrm{x}$ & $0.52(0.10-2.78)(-)$ & $\mathrm{x}$ & $\mathrm{x}$ \\
\hline Centre has its own MRI scan & $0.73(0.44-1.20)(-)$ & $\mathrm{x}$ & $\mathrm{x}$ & $\mathrm{x}$ \\
\hline \multicolumn{5}{|l|}{ Background characteristics } \\
\hline Gender & $0.96(0.34-2.70)(-)$ & $1.12(0.37-3.45)(+)$ & $\mathrm{x}$ & $\mathrm{x}$ \\
\hline $\mathrm{Age}^{\mathrm{c}}$ & $1.00(0.97-1.04)$ & $0.96(0.92-1.00)(-)$ & $\mathrm{x}$ & $1.10(0.88-1.36)(+)$ \\
\hline $\begin{array}{l}\text { Years of experience as an } \\
\text { orthopaedic surgeon }\end{array}$ & $1.00(0.96-1.04)$ & $0.95(0.92-0.99)(-)$ & $\mathrm{x}$ & $0.88(0.70-1.11)(-)$ \\
\hline \multicolumn{5}{|l|}{ Work setting } \\
\hline University medical centre & $2.20(0.47-10.30)(+)$ & $1.95(0.42-9.19)(+)$ & $\mathrm{x}$ & $\mathrm{x}$ \\
\hline Teaching hospital & $1.61(0.77-3.67)(+)$ & $1.89(0.85-4.18)(+)$ & $\mathrm{x}$ & $\mathrm{x}$ \\
\hline Private clinic & $0.63(0.27-1.47)(-)$ & $0.55(0.23-1.31)(-)$ & $\mathrm{x}$ & $\mathrm{x}$ \\
\hline General hospital & Reference category & Reference category & $\mathrm{x}$ & $\mathrm{x}$ \\
\hline \multicolumn{5}{|l|}{ Work region } \\
\hline North & Reference category & Reference category & $\mathrm{x}$ & Reference category \\
\hline Middle & $1.39(0.69-2.82)(+)$ & $2.54(1.17-5.53)(+)$ & $\mathrm{x}$ & $1.97(0.61-6.37)(+)$ \\
\hline South & $1.60(0.69-3.71)(+)$ & $1.52(0.67-3.44)(+)$ & $\mathrm{x}$ & $0.98(0.30-3.16)(-)$ \\
\hline
\end{tabular}

OR $(95 \% \mathrm{CI})=$ odds ratio $(95 \%$ confidence interval), $(-)$ barrier, $\mathrm{OR}<1,(+)$ facilitator, $\mathrm{OR}>1$. In bold: $p$ values $\leq 0.05$

$n=252$

${ }^{\mathrm{a}} n=247$

$\mathrm{b}_{n}=245$

${ }^{c} n=244$

${ }^{\mathrm{d}}$ Could not be estimated

the use of MRI and arthroscopies in degenerative knee disease mainly mentioned clinician-related barriers [24, 28], it was shown by this study that also patients' preferences for MRIs and positive experiences of people in their environment with arthroscopies hampered implementation of the $\mathrm{CW}$ recommendations. This is an important finding for future initiatives to improve implementation of $\mathrm{CW}$ recommendations. These should include both patient- and orthopaedic surgeon-directed strategies.

Implications for clinical practice are that the use of unnecessary MRIs and knee arthroscopy for patients with degenerative knee disease can potentially be reduced by strategies tailored to the identified barriers for implementation of the $\mathrm{CW}$ recommendations [11]. This reduction is of great importance as MRIs and arthroscopies for patients with degenerative knees provide no benefit for the patient, waste resources and may even cause harm to the patient $[17,35]$.

Although this study identified important starting points for improving implementation of $\mathrm{CW}$ recommendations, there are also limitations. First, only three patients and three orthopaedic surgeons were interviewed for survey development. However, after the second interview with the orthopaedic surgeon, no new information was obtained so more interviews were not required. Besides, the interviews were only used to explore if other factors should be included in the survey than already found in the literature. The second limitation is the retrospective nature of this study and the use of self-reported questions. Both patients and orthopaedic surgeons were asked to report 
the characteristics of received care/care delivery and barriers/ facilitators retrospectively, and the use of $\mathrm{CW}$ recommendation. Therefore, it is possible that some patients and orthopaedic surgeons were not able to fully recall their respective care trajectory and provided care. Third, patients were self-selected after seeing the advertisements in the newspapers or on the websites, which may have caused selection bias. However, it seems that the patients who completed the survey represented the target group well [5].

\section{Conclusions}

The identified factors give important starting points for improving implementation of the $\mathrm{CW}$ recommendations regarding MRIs and arthroscopies in degenerative knee disease. It seems important to search for strategies to change clinician beliefs on the added value of arthroscopies and MRIs. Moreover, these strategies should focus on the importance of clinical experiences based on evidence. Furthermore, patientdirected strategies are needed to address patient 'subjective' preferences based on social feedback from environment and social media. These may add to underlying misbeliefs on the value of MRI and arthroscopies in degenerative knee disease.

Funding This study was funded by the Netherlands Organization for Health Research and Development (ZonMw) Grant 8392010022. They have no role in the study design or analysis.

\section{Compliance with ethical standards}

Conflict of interest The authors declare that they have no competing interests.

Ethical approval This study was approved by the Medical Ethical Committee (CME P16.190/NV/nv) of the Leiden University Medical Center.

Informed consent For this type of article, formal consent is not required.

Open Access This article is distributed under the terms of the Creative Commons Attribution 4.0 International License (http://creativeco mmons.org/licenses/by/4.0/), which permits unrestricted use, distribution, and reproduction in any medium, provided you give appropriate credit to the original author(s) and the source, provide a link to the Creative Commons license, and indicate if changes were made.

\section{Appendix 1: Items survey patient}

\begin{tabular}{|c|c|}
\hline \multicolumn{2}{|l|}{ Background characteristics } \\
\hline Age & In years \\
\hline Gender & Male, female \\
\hline Region of residence & $\begin{array}{l}\text { North (Friesland, Groningen, Flevoland, Noord-Holland, Drenthe, and Overijssel), middle (Zuid- } \\
\text { Holland, Utrecht, and Gelderland) and south (Noord-Brabant, Zeeland, and Limburg) }\end{array}$ \\
\hline Education level & $\begin{array}{l}\text { Basic education (no or only primary education), intermediate education (prevocational secondary educa- } \\
\text { tion, senior secondary vocational training, senior secondary general education, pre-university education) } \\
\text { or higher education (higher professional education or university (bachelor's, master's or PhD degree) }\end{array}$ \\
\hline Start of disease symptoms & 0-3 months, 3-6 months, $6-12$ months, and $>1$ year \\
\hline $\begin{array}{l}\text { Diagnosis of locking symptoms by } \\
\text { orthopaedic surgeon if patient received } \\
\text { arthroscopy }\end{array}$ & Yes, no \\
\hline \multicolumn{2}{|c|}{ Pain before visiting an orthopaedic surgeon Visual analogue scale (VAS) } \\
\hline Pain at the moment of the survey & Visual analogue scale (VAS) \\
\hline Health insurance & Basic insurance or additional coverage $\mathrm{a}^{\mathrm{a}}$ \\
\hline \multicolumn{2}{|l|}{ Characteristics of the received care } \\
\hline History of caregivers & General practitioner (GP), physical therapist, orthopaedic surgeon, dietitian, and/or other \\
\hline Received care modalities & MRI, arthroscopy and/or physical therapy (yes/no) \\
\hline $\begin{array}{l}\text { Time between start of knee complaints } \\
\text { and visiting the GP }\end{array}$ & $<1$ week, $1-6$ weeks, $>6$ weeks, or no idea \\
\hline $\begin{array}{l}\text { Waiting time between GP and orthopae- } \\
\text { dic surgeon }\end{array}$ & $1-2$ weeks, 3-4 weeks, 5-6 weeks, more than 6 weeks, or no idea \\
\hline Waiting time MRI & 1-2 weeks, 3-4 weeks, 5-6 weeks, more than 6 weeks, or no idea, not applicable (NA) \\
\hline Waiting time arthroscopy & Waiting time arthroscopy (1-2 weeks, 3-4 weeks, 5-6 weeks, more than 6 weeks, or no idea, NA) \\
\hline $\begin{array}{l}\text { Preferred and actual role of the patient in } \\
\text { treatment decision-making process }\end{array}$ & Control Preference Scale (CPS) [17] \\
\hline
\end{tabular}

${ }^{\text {a } I n ~ t h e ~ N e t h e r l a n d s, ~ a p p l y i n g ~ f o r ~ a ~ b a s i c ~ i n s u r a n c e ~ i s ~ c o m p u l s o r y . ~ I n ~ a d d i t i o n, ~ p a t i e n t s ~ c a n ~ c h o o s e ~ f o r ~ a n ~ a d d i t i o n a l ~ c o v e r a g e ~}$ 


\section{Appendix 2: Items survey orthopaedic surgeon}

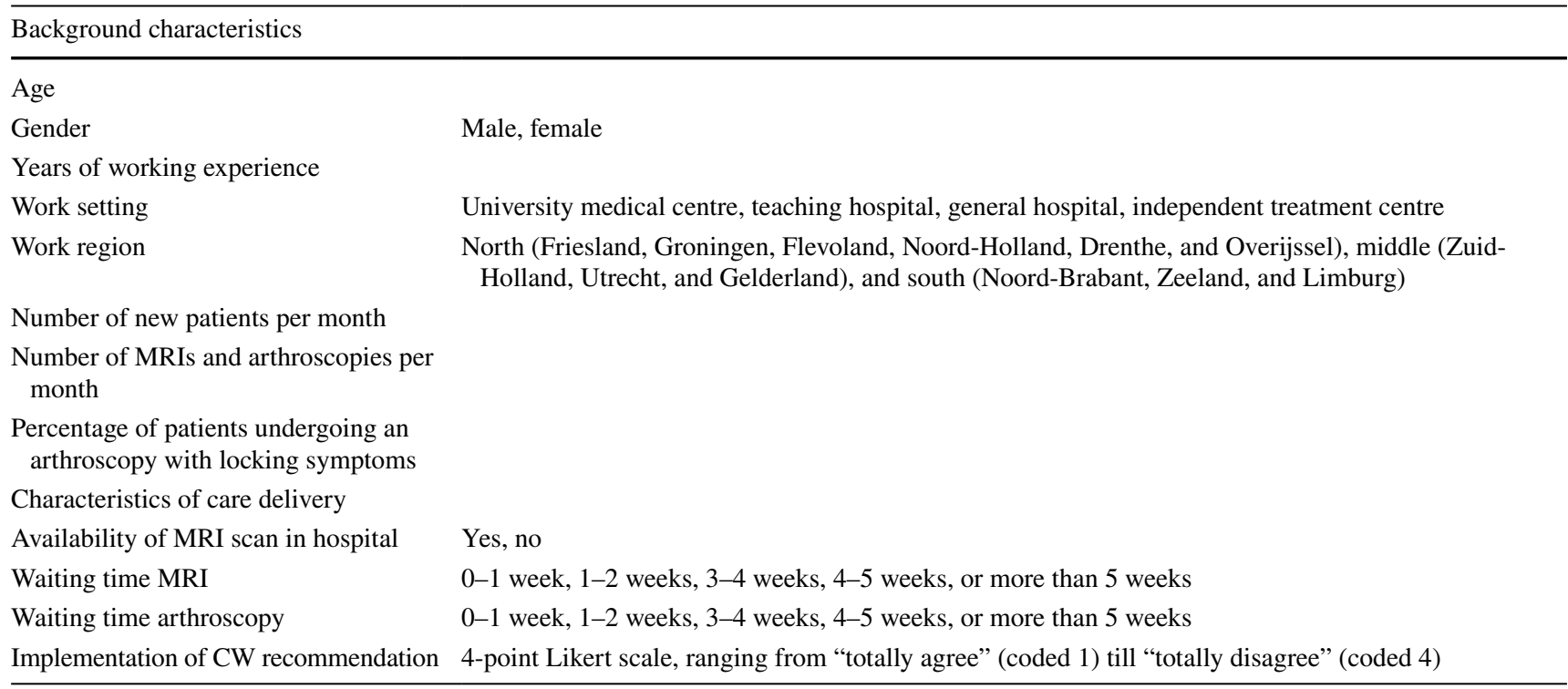

\section{Appendix 3: Flowcharts}

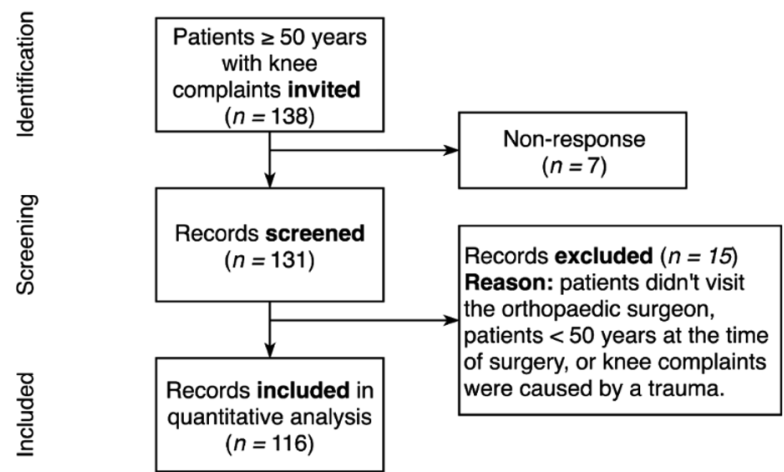

Flowchart patients

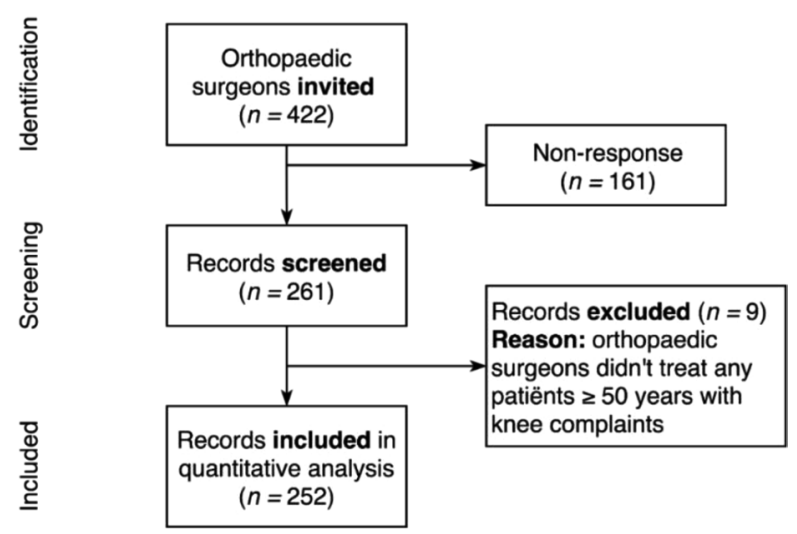

Flowchart orthopaedic surgeons

\section{References}

1. American Medical Society for Sports Medicine (2014) Five things physicians and patients should question. http://www.choosingwi sely.org/societies/american-medical-society-for-sports-medicine/. Accessed 13 Feb 2019

2. Arthroscopy of the knee (in Dutch) (2019) https://richtlijnendata base.nl/richtlijn/artroscopie_van_de_knie/startpagina_-_artro scopie_van_de_knie.html. Accessed 13 Feb 2019

3. Australian Rheumatology Association (2018) tests, treatments and procedures clinicians and consumers should question. http:// www.choosingwisely.org.au/recommendations/ara. Accessed 13 Feb 2019

4. ESSKA Meniscus Consensus Project (2016) Degenerative meniscus lesions. https://cdn.ymaws.com/www.esska.org/resource/ resmgr/Docs/2016-meniscus-consensus-proj.pdf. Accessed 13 Feb 2019

5. Medical specialist care (2018) Diagnosis treatment combination (DTC) to diagnosis (in Dutch). https://opendata.cbs.nl/statline/\#/ $\mathrm{CBS} / \mathrm{nl} /$ dataset $/ 82470 \mathrm{NED} /$ table $? \mathrm{ts}=1540560239360$. Accessed $13 \mathrm{Feb} 2019$

6. Orthopaedics (2018) Ten things physicians and patients should question. https://choosingwiselycanada.org/orthopaedics/. Accessed 13 Feb 2019

7. Osteoarthritis: care and management 2014 https://www.nice.org. uk/guidance/cg177. Accessed 13 Feb 2019

8. VA/DoD Clinical Practice Guideline For The Non-Surgical Management of Hip and Knee Osteoarthritis (2014) https://www.healt hquality.va.gov/guidelines/CD/OA/VADoDOACPGFINAL09021 4.pdf. Accessed 13 Feb 2019

9. Adelani MA, Harris AH, Bowe TR, Giori NJ (2016) Arthroscopy for knee osteoarthritis has not decreased after a clinical trial. Clin Orthop Relat Res 474:489-494

10. Al Sayah F, Williams B, Pederson JL, Majumdar SR, Johnson JA (2014) Health literacy and nurses' communication with type 2 diabetes patients in primary care settings. Nurs Res 63:408-417

11. Baker R, Camosso-Stefinovic J, Gillies C, Shaw EJ, Cheater F, Flottorp S et al (2015) Tailored interventions to address 
determinants of practice. Cochrane Database Syst Rev. https:// doi.org/10.1002/14651858.cd005470.pub3

12. Barlow T, Plant CE (2015) Why we still perform arthroscopy in knee osteoarthritis: a multi-methods study. BMC Musculoskelet Disord 16:85

13. Bergkvist D, Dahlberg LE, Neuman P, Englund M (2016) Knee arthroscopies: who gets them, what does the radiologist report, and what does the surgeon find? An evaluation from southern Sweden. Acta Orthop 87:12-16

14. Bhattacharyya TMD, Gale DMD, Dewire PMD, Totterman SMD, Gale MEMD, McLaughlin SMPH et al (2003) The clinical importance of meniscal tears demonstrated by magnetic resonance imaging in osteoarthritis of the knee. J Bone Jt Surg Am 85:4-9

15. Bijlsma JW, Berenbaum F, Lafeber FP (2011) Osteoarthritis: an update with relevance for clinical practice. Lancet 377:2115-2126

16. Bohensky MA, Sundararajan V, Andrianopoulos N, de Steiger RN, Bucknill A, Kondogiannis CM et al (2012) Trends in elective knee arthroscopies in a population-based cohort, 2000-2009. Med J Aust 197:399-403

17. Brignardello-Petersen R, Guyatt G, Buchbinder R, Poolman R, Schandelmaier S, Chang Y et al (2017) Knee arthroscopy versus conservative management in patients with degenerative knee disease: a systematic review. BMJ Open 7:e016114

18. Buchbinder R, Harris IA, Sprowson A (2015) Management of degenerative meniscal tears and the role of surgery. BMJ 350:h2212

19. Englund M (2008) The role of the meniscus in osteoarthritis genesis. Rheum Dis Clin N Am 34:573-579

20. Englund M, Guermazi A, Gale D, Hunter DJ, Aliabadi P, Clancy $M$ et al (2008) Incidental meniscal findings on knee MRI in middle-aged and elderly persons. N Engl J Med 359:1108-1115

21. Fleuren P, van Dommelen P, van Buren SV (2012) Measuring instrument for determinants of innovations (MIDI) (in dutch). Int J Qual Health Care 26:501-510

22. Flottorp SA, Oxman AD, Krause J, Musila NR, Wensing M, Godycki-Cwirko $\mathrm{M}$ et al (2013) A checklist for identifying determinants of practice: a systematic review and synthesis of frameworks and taxonomies of factors that prevent or enable improvements in healthcare professional practice. Implement Sci 8:35

23. Grol R, Wensing M (2004) What drives change? Barriers to and incentives for achieving evidence-based practice. Med J Aust 180:S57-S60

24. Hamilton DF, Howie CR (2015) Knee arthroscopy: influence of systems for delivering healthcare on procedure rates. BMJ 351:h4720

25. Hofstede SN, Marang-van de Mheen PJ, Vliet Vlieland TP, van den Ende CH, Nelissen RG, van Bodegom-Vos L (2016) Barriers and facilitators associated with non-surgical treatment use for osteoarthritis patients in orthopaedic practice. PLoS One 11:e0147406

26. Hunter DJ, Bierma-Zeinstra S (2019) Osteoarthritis. Lancet 393:1745-1759

27. Ikuta F, Takahashi K, Hashimoto S, Mochizuki Y, Yuzawa Y, Inanami $\mathrm{H}$ et al (2019) Effect of physical therapy on early knee osteoarthritis with medial meniscal posterior tear assessed by MRI $\mathrm{T} 2$ mapping and 3D-to-2D registration technique: a prospective intervention study. Mod Rheumatol. https://doi.org/10.1080/14397 595.2019.16461931-10

28. Jarvinen TL, Guyatt GH (2016) Arthroscopic surgery for knee pain. BMJ 354:i3934

29. Katz JN, Brophy RH, Chaisson CE, de Chaves L, Cole BJ, Dahm DL et al (2013) Surgery versus physical therapy for a meniscal tear and osteoarthritis. N Engl J Med 368:1675-1684

30. Khan M, Evaniew N, Bedi A, Ayeni OR, Bhandari M (2014) Arthroscopic surgery for degenerative tears of the meniscus: a systematic review and meta-analysis. CMAJ 186:1057-1064
31. Kise NJ, Risberg MA, Stensrud S, Ranstam J, Engebretsen L, Roos EM (2016) Exercise therapy versus arthroscopic partial meniscectomy for degenerative meniscal tear in middle aged patients: randomised controlled trial with 2 year follow-up. BMJ 354:i3740

32. Muheim LLS, Senn O, Fruh M, Reich O, Rosemann T, NeunerJehle SM (2017) Inappropriate use of arthroscopic meniscal surgery in degenerative knee disease. Acta Orthop 88:550-555

33. Parent ME, Vezina F, Carrier N, Masetto A (2018) Indications for and clinical procedures resulting from magnetic resonance imaging of the knee in older patients: are we choosing wisely? Can Fam Physician 64:e126-e132

34. Rosenberg A, Agiro A, Gottlieb M, Barron J, Brady P, Liu Y et al (2015) Early trends among seven recommendations from the Choosing Wisely campaign. JAMA Intern Med 175:1913-1920

35. Scott IA, Duckett SJ (2015) In search of professional consensus in defining and reducing low-value care. Med J Aust 203:179-181

36. Sears ED, Caverly TJ, Kullgren JT et al (2016) Clinicians' perceptions of barriers to avoiding inappropriate imaging for low back pain-knowing is not enough. JAMA Intern Med 176:1866-1868

37. Siemieniuk RAC, Harris IA, Agoritsas T, Poolman RW, Brignardello-Petersen R, Van de Velde S et al (2017) Arthroscopic surgery for degenerative knee arthritis and meniscal tears: a clinical practice guideline. BMJ 357:j1982

38. Sihvonen R, Paavola M, Malmivaara A, Itälä A, Joukainen A, Nurmi H et al (2013) Arthroscopic partial meniscectomy versus sham surgery for a degenerative meniscal tear. N Engl J Med 369:2515-2524

39. Subhas N, Sakamoto FA, Mariscalco MW, Polster JM, Obuchowski NA, Jones MH (2012) Accuracy of MRI in the diagnosis of meniscal tears in older patients. AJR Am J Roentgenol 198:W575-W580

40. Thorlund JB, Hare KB, Lohmander LS (2014) Large increase in arthroscopic meniscus surgery in the middle-aged and older population in Denmark from 2000 to 2011. Acta Orthop 85:287-292

41. Turkiewicz A, Gerhardsson de Verdier M, Engstrom G, Nilsson PM, Mellstrom C, Lohmander LS et al (2015) Prevalence of knee pain and knee OA in southern Sweden and the proportion that seeks medical care. Rheumatology (Oxford) 54:827-835

42. van Bodegom-Vos L, Davidoff F, Marang-van de Mheen PJ (2017) Implementation and de-implementation: two sides of the same coin? BMJ Qual Saf 26:495-501

43. van de Graaf VA, Noorduyn JCA, Willigenburg NW, Butter IK, de Gast A, Mol BW et al (2018) Effect of early surgery vs physical therapy on knee function among patients with nonobstructive meniscal tears: the escape randomized clinical trial. JAMA 320:1328-1337

44. Yim J-H, Seon J-K, Song E-K, Choi J-I, Kim M-C, Lee K-B et al (2013) A comparative study of meniscectomy and nonoperative treatment for degenerative horizontal tears of the medial meniscus. Am J Sports Med 41:1565-1570

45. Zhang W, Doherty M, Peat G, Bierma-Zeinstra MA, Arden NK, Bresnihan B et al (2010) EULAR evidence-based recommendations for the diagnosis of knee osteoarthritis. Ann Rheum Dis 69:483-489

46. Zikmund-Fisher BJ, Kullgren JT, Fagerlin A, Klamerus ML, Bernstein SJ, Kerr EA (2017) Perceived barriers to implementing individual Choosing Wisely $(\mathrm{R})$ ) recommendations in two national surveys of primary care providers. J Gen Intern Med $32: 210-217$

Publisher's Note Springer Nature remains neutral with regard to jurisdictional claims in published maps and institutional affiliations. 